DOI: $10.24193 /$ tras.62E. 5

Published First Online: 02/25/2021

\title{
STUDY OF THE TRANSFORMATION \\ OF INDUSTRIAL HERITAGE FROM \\ THE PERSPECTIVE OF HOLISTIC \\ GOVERNANCE
}

\author{
Zhang HUA \\ LiU YANING \\ Jilong WANG
}

\section{Zhang HUA}

Associate professor, $\mathrm{PhD}$,

Film-Television and Communication College,

Shanghai Normal University, Shanghai, China

Tel.: 00861-316-611.0175

E-mail: zhangh79@shnu.edu.cn

\section{Liu YANING}

Student, Film-Television and Communication College, Shanghai Normal University, Shanghai, China

In the past few years, with the development of technology and industrial upgrading, a growing number of countries are facing the problem of how to transform their industrial heritages, especially if they are in downtowns. Public administration top managers have a main role in this complex process of purpose and ownership changes. By examining the transformation of industrial heritage in Shanghai - a case-study examined through interviews, chronology of events and content analyses -, this paper explores how the government has used the idea of holistic governance in creating an exhaustive plan and implementing it. The study also explores the government's attempt to build social consensus regarding that major transition, including the role of communication with citizens.

Keywords: industrial heritage, public administration, holistic governance, power relation, networking.

\section{Jilong WANG (corresponding author)}

Professor, PhD, School of Media and Communication, Shanghai Jiao Tong University, Shanghai, China

Tel.:00861-381-720.7469

E-mail: jlwang@sjtu.edu.cn 


\section{Introduction}

In the 1970s and 1980s, large-scale deindustrialization movements began in Western Europe and North America (Altena and van der Linden, 2002). Citizens, public administration managers and legal experts have raised questions about the transformation of the industrial heritage. As an example, the VolklingerHutte plant in Saarland, Germany, an extraordinarily lucrative company during the steel age, ceased production in 1986 and was successfully listed on The World Heritage List in 1994 as the first industrial heritage in the world (UNESCO, 2020). Through an innovative process, it has become a cultural center and an industrial tourism site. Along with the industrial transformation and upgrading in the contemporary era, and because of new environment regulations, heavy and textile industries have been moving out of the cities, leaving former industrial land abandoned. From defining industrial heritage to adding more and more industrial heritage into the World Heritage centers, UNESCO has been very active in stimulating the transformation of industrial heritage first in Europe and the United States, then in the rest of the world (UNESCO, 2020).

Many countries have made the choice to redesign industrial heritage into public facilities, because the architecture of the industrial era enables this transformation. The challenges of brownfield reconstruction are mostly related to funding and policies. The essence of this process is the gradual replacement of the former enterprise management through public coordination and administration. The government needs to administer various resources and to deal with complex power relations during the implementation of the project. For example, the transformation of mining areas in the Ruhr region of Germany needed a lot of financial support. The European Union, the German state and municipal governments, as well as associations such as the RAG (Ruhrkohle AG) Foundation and large enterprises have provided funding (Zhang and Liu, 2020). In terms of complexity, the case of the Iron Bridge Gorge in the U.K. also is relevant: this reconstructed industrial heritage consists of seven monuments and museums and 285 protected industrial buildings - a vast project that transformed factories, warehouses, mining areas, workers' dormitories, transportation roads and other facilities (Baidu Baike, 2020). As we mentioned before, rules and regulations are needed for the implementation of such projects. In Japan, for instance, a special committee for cultural properties protection planning was established in 1992. In its 1994 report, the committee extended the protection of cultural properties to modern heritage, including industrial heritage born in modern times. In 1996, the 'Building Registration System' was approved by the Japanese Parliament and the protection and renovation of industrial heritage was officially launched.

The period of industrial heritage transformation in the world overlaps with the birth and development of new public management and integrated management in the field of public administration. These new trends have more or less affected the industrial heritage transformation in various countries (Hood, 1991). The new public administration - with its focus on business management technology - has created competition mechanisms and customer orientation. Though there is no direct evi- 
dence that the worldwide industrial heritage transformation completely follows the new public management principles, the theoretical framework of public management plays an important role in the construction of public spaces, including industrial heritage. There are variations from one country to another in the system design and other aspects of the reform, as well as different options in management practice and reform depth. Sometimes, the new public administration theory and practice have led to the fragmentation of government management, a lack of communication, breaks in the decision-making process, eventually impacting the citizens and the efficiency of the public services that they receive. Successful cases have shown that the transformation of industrial heritage needs to be guided by a collaborative governance approach, with a lot of attention paid to transparency and good communication. They also have proven that public administration managers should learn from the competitive corporate culture and from market mechanisms, but also to consider principles such as of social equality, justice and other democratic values.

China began large-scale industrial constructions after the founding of the People's Republic in 1949. Since the 1980s, the reform and open policy have promoted the development of all sectors of production, including the industry. However, the modernization of the production process and the growing focus on IT technologies, unused or underused large-scale industrial properties have become an issue of concern. According to the national soil pollution survey communique released in 2014, the soil environment in China's abandoned industrial lands is a serious problem, accounting for $34.9 \%$ of the areas where the pollution exceeds the standard (China Soil Pollution Status Survey Bulletin, 2014). 'The Comprehensive Work Plan for Energy Conservation, Emission Reduction and Greenhouse Gas Emission Control of Shanghai During the 13th Five-Year Plan Period' (General Office of Shanghai Municipal Government, 2018) stipulates that the adjustment and elimination of processes

and products with high energy consumption, high emissions and low added value should be promoted. The plan envisions that, by the end of 2020, 3,500 enterprises in 50 key regions are going to go through this process of transformation (Shanghai Government, 2018). Experts have called for the transformation and regeneration of the abandoned industrial land. What has been the theoretical framework for the implementation of this process? What were the steps of the transition from enterprise management to public management? How does the government continue to coordinate this project? This paper aims to respond to these questions through an analysis build on a case study and multiple interviews.

\section{Literature review: The new management path of industrial heritage research}

The rise of holistic governance theory is based on the gradual decline of new public management and the advent of internet digital technology. Since the beginning of the 21st century, the concept of holistic governance has penetrated into the public administration, with the aid of information technologies and mobile internet. It requires 
appropriate division of work and cooperation between government departments and internal and external government agencies under the overall guidance of comprehensive thinking, and emphasizes the use of competition and incentive policies. This management style ultimately seeks to make better use of scarce resources, to produce synergy by aggregating stakeholders in a specific policy field, and to provide seamless rather than fragmented public services to the public (Pollit, 2003). In the process of industrial heritage transformation, it is necessary to emphasize the concept of holistic governance and explore the power relationship between internal and external government agencies.

As of July 11, 2019, 272 papers including 'industrial heritage' in the title could be retrieved by using Web of Science (see Table 1 for details.) The research topics are mainly about the preservation and protection of industrial heritage, the beautification of industrial heritage and the tourism of industrial heritage.

Table 1: Frequency ranking of the research direction of papers related to industrial heritage

\begin{tabular}{lcc}
\hline \multicolumn{1}{c}{ Research Orientation } & Frequency & Ranking \\
\hline ARTS HUMANITIES OTHER TOPICS & 48 & 1 \\
\hline ARCHITECTURE & 46 & 2 \\
\hline HISTORY & 38 & 3 \\
BUSINESS ECONOMICS & 37 & 4 \\
SOCIAL SCIENCES OTHER TOPICS & 36 & 5 \\
GEOGRAPHY & 32 & 6 \\
ENGINEERING & 30 & 7 \\
ENVIRONMENTAL SCIENCES ECOLOGY & 27 & 8 \\
ART & 25 & 9 \\
ARCHAEOLOGY & 19 & 10 \\
\hline
\end{tabular}

In the process of industrial heritage development and transformation, governments of all countries have recognized the important value of industrial heritage and have taken corresponding measures. In Western European countries, public policy often believes that heritage, especially industrial heritage, can be an effective resource for economic and social development in regions seriously affected by deindustrialization (Orange, 2008). In terms of policies, Great Britain and France had different approaches in the 1990s to define the role of industrial heritage in the era of deindustrialization. Generally, the UK promotes tourism, while France prefers cultural projects (Orange, 2008). In the process of industrial heritage protection and utilization, scholars have argued on how to deal with the contradictions between system, policy designation, academia and local residents. Del Pozo and Gonzales (2012) argued that since the 1980s, Spain had attached great importance to the protection of industrial heritage, but there were obvious inconsistencies between the system, academic initiatives and local communities. Orange (2008) provided more specific examples in the comparison 
of British and French policies. Local authorities and local power play important roles in heritage politics, especially in Great Britain. These politics are influenced by the struggles and tensions between local residents and 'outside' agents (Orange, 2008). The number of studies is not large, and they lack the perspective of public management as a whole. The existing research mainly focuses on the role of government departments in industrial heritage transformation. When it comes to the management work, the research on how to carry out more efficient industrial heritage transformation is very limited. Although the idea of holistic governance has been deep involved in the transformation process of industrial heritage, the role played by this new path and the change of management mode caused by the transformation have not attracted the attention of the academic community. The transformation of industrial heritage of China still relies on groping forward, relying on the summary of successful cases to put forward ideas for the follow-up management work. Therefore, it has become a very important topic to sort out the changes of power relations in the process of industrial heritage transformation in theory. This provides information on how the government can provide better public space and public services for citizens under the thinking of holistic governance.

\section{Methodology}

Industrial heritages around the world are determined and defined by their own environment, national system, social stage and other factors. Each industrial heritage has its unique historical reasons of existence and evolution, as well as its specific environment. The industrial heritage management methods also are quite different from a country to another. This paper has chosen the case-study method to explore the practice of holistic governance in the process of industrial heritage transformation, by taking Shanghai Binjiang industrial heritage transformation as the main research topic. From March to June 2019, we interviewed government officials and participating enterprise leaders, and randomly interviewed surrounding residents and tourists in the Xuhui Binjiang to analyze how the process has taken place. We examined documents issued during all the phases of the project, including regulations, the establishment of relevant departments, land storage, overall planning, and investment promotion. This study argues that the government, as a public management institution, needs to reexamine the transformation of industrial heritage through the perspective of holistic administration, and to explore a new, efficient and comprehensive path of public management for the transformation and utilization of industrial heritage.

Through text analysis method and case study, we examined the dynamics of the power relationships in the transformation process of industrial heritage from brownfield to public space, to see how the government gradually replaced enterprise management to transition to public management. Our goal was to examine the theory of holistic governance and its role in how the government provides the public with better public space and public services in the process of industrial heritage transformation. 


\section{Becoming a brownfield: from enterprise management to public management}

After the industrial revolution, machine production replaced human resources, and the world began to change from handicraft industry to large-scale enterprises. Upon the beginning of the era of large-scale machinery production, industrial buildings - such as factories and warehouses - and transportation facilities (terminals and airports) have developed on a large scale in the world. In this stage, the factory machinery was a lively means of production, constantly creating wealth. In the factory space, the management operation completely followed the logic of enterprise management, based on efficiency first, and with the workers having a clear division of labor on the assembly line. Managers at all levels followed a strict management hierarchy, and their power relationship was defined from top to bottom according to the enterprise structure. When the government provided public services, it often took the enterprise as a whole to coordinate the relationship between the factory, the surrounding residents, and other public services. In other words, in this period, the internal operation logic of the factory followed the enterprise management. At the same time, the public management used the mass media to spread the image of these factories, and to present them as an asset that created wealth for the whole society. For example, the Ruhr Industrial Base in Germany, originally a remote and unknown natural landscape, had gradually found rich mineral resources. The formation of mining facilities and steel plants brought a huge economic leap to Ruhr district. By the 19th century, Ruhr had become a famous heavy industry area in the world. Through the mass media, the coal industry was represented as an example of advanced productivity and wealth creation, illustrating the government's management power in the industrial era.

After the Second World War, the industrial structure around the world changed. During this period, many industrial buildings, such as factory buildings, warehouses, mines and railways, became industrial heritages and scars of urban garbage and nature, thus forming brownfield. At the same time, with the relocation or closure of factories, a large number of workers fell into the plight of unemployment. The enterprise management logic, that had previously been dominant among them, failed with the closure of factories, and the power structure based on profit and efficiency also collapsed rapidly. The improper discharge of industrial waste, sewage and waste gas left by the factories caused the deterioration of the surrounding environment and ecological damage of the industrial heritage, and affected the quality of life of the residents near the factory. The government-led public management was often unable to replace the enterprise management to extend into the brownfield in time, or reconstruct the space after the original power structure was removed. The power structure of the brownfield basically collapsed, the areas lacking management further accelerated the decline, and the impact on the surrounding residents became more and more negative. A power vacuum occurred in the area where the plant was located, with the abandoned factories and surrounding residents forming an undesired relationship. 
The desolate and decaying industrial area became a ruin of the city. Therefore, in order to seek a better living environment, the economically capable residents moved away. Industrial heritage and its surrounding environment became the residential areas for the poor and low-income people, and the areas with low land prices and relatively backward public services. At that time, people who were not familiar with those areas did not realize the seriousness of the problem.

Government intervention in the transformation of these regions needed a large number of resources. In the absence of consensus, forced intervention of public management was not the first choice of most governments. Gradually, public opinion leaders and experts representing local residents appealed through various channels, and the most common was mass media. The image of factories in the media was no longer a symbol of modernization and wealth production, but rather an unwanted source of air and river pollution. Those governments that were aware of these issues tried to use the mass media to set a new agenda, to promote the urgency of industrial heritage transformation, and to reach consensus at a broader level of society. At that stage, it was necessary to use the idea of holistic governance for guidance. Using mass media, setting agenda and forming social consensus would not only lay the foundation for the government's public management intervention, but also prepare the planning and transformation process.

In Shanghai, the 2010 World Expo was an opportunity for the city to reconstruct the industrial sites on both sides of the Huangpu River. The government used the mass media to set up the discourse, and the decline of the industrial heritage area enabled the public to reach a consensus regarding the transformation of industrial heritage, which had become a topic of concern and debate. Through the dissemination of the planning and construction of the World Expo, the public gradually agreed that the transformation of industrial heritage into expo related pavilions would bring better urban life. At that time, the government gradually intervened, and emphasized the necessity and importance of industrial heritage transformation from the perspective of social consensus. The government's intervention on behalf of public management was based on the idea of holistic governance, with focus on the necessity of a correlation among all participants in and steps of the process, including planning and timeline.

\section{Transforming brownfield: holistic governance dominated by network power structure}

The Shanghai government started the process with the assumption that industrial heritage consists of two parts: architecture and its spatial significance and function. The options for the transformation and utilization process of industrial heritage were: 1) to keep the buildings, add new spatial meanings and functions on the premise of preserving the appearance of industrial heritage buildings to the maximum extent (for example, the hangar of Shanghai Jiangnan Shipyard was transformed into a theme exhibition hall during the Expo); 2) to retain the meaning and function, remod- 
el the building, and reappear the production process of the industrial era through the establishment of the experiential immersive industrial museum; and 3) to dismantle the industrial buildings with low historical and cultural significance, rebuild in this area, restore its green area, and provide more urban landscape and public space. No matter which of these transformation methods, it is necessary to coordinate various stakeholders, especially in the process of the transformation of large-scale industrial heritage, not only one mode is often adopted, but also the overall communication and coordination, and the government is required to intervene.

In the process of becoming a brownfield, through the repeated communication between the government, the media and the public, the society has often formed a broad consensus to transform the industrial rustbelt. At this time, the government, on behalf of the public interest, has the legitimacy of public opinion to start the transformation of industrial heritage. Meanwhile, the management logic on the brownfield is gradually changing from the state of power vacancy to the mode of public management leading. At this stage, the government needs to coordinate the relationships among various government departments, industrial heritage owners, surrounding residents, infrastructure construction providers, various enterprises involved in the construction, public space operation enterprises, social forces and many other stakeholders, so as to carry out orderly and efficient transformation with consistent goals. Especially with the help of some large-scale events, public activities to promote the industrial heritage transformation, often limited by the time of the event, the government will have an extremely urgent need for efficient coordination and communication. The work led by the new public management concept can achieve efficiency in a single department or field, but there will be obvious defects when it comes to the coordination of multiple subjects and departments. Therefore, the idea of holistic governance becomes an important choice in the process of industrial heritage transformation.

Under the premise of forming a huge social consensus in the previous period, some enterprises actively donated brownfield to the government, and the government led the unified transformation. Some enterprises contributed the ownership of brownfield to participate in the transformation, such as, in 2009, Shangtex Holding Co., Ltd. (its Chunming Coarse Textile Factory was located there). In 2011, the new company officially changed the name of 'Chunming Art Industrial Park' (used after 2004) to 'Shanghai M50 Cultural and Creative Industry Development Co., Ltd.', and comprehensively developed the industrial heritage on the site. Before the 2010 Shanghai World Expo was held, the government formed a broad social consensus on the transformation of brownfields through extensive publicity. For example, under the coordination of the Xuhui District Government in Shanghai, 116 enterprises in brownfields or brownfield annexes have completed the relocation, involving the relocation of more than 3,500 households in the surrounding area. The land collection and storage are about 280 hectares, and the reconstruction of the hydrophilic shoreline is 3.6 kilometers. 300,000 square meters of public space and 20 kilometers of urban roads promote the transformation of the riverside shoreline from a productive 
function to a living function. In addition to publicizing these plans and data through mass media, the Xuhui Binjiang Exhibition Center is currently open to the public through sandboxes, photoelectric systems, and multimedia display systems.

Under the guidance of holistic governance, the Bureau of Planning and Natural Resources - after extensive consultation with stakeholders, the public and experts -, made an overall planning for brownfield and determined the public space, industrial form, community scale, hospital and school locations in the field. In this process, the application of internet information technology greatly empowered the public individuals. They expressed their views and opinions on industrial heritage transformation on public platforms such as government websites and government accounts in social media. Combined with the past e-mail, government hotline and other ways, it greatly improved the efficiency of communication between the government and the public, and mobilized the participation of many individuals. The final planning goal was approved by the legislature and publicized to the public, became mandatory by law, and represented the guideline for all specific work in the later stages.

On this basis, the planning department of the government formulated the planning plan in accordance with the relevant laws and the overall urban development framework. This document also represented the government's efforts to provide employment opportunities, improve the environment and protect the public interest. It is the most direct and in-depth intervention of public management in the process of industrial heritage transformation, and it is the representation of the idea of holistic governance. In this process, the government has directly implemented the planning through authority and administrative orders. When it comes to the coordination of multiple interest groups or complex relations, it is often necessary for the head of government to personally coordinate various relations and promote collaboration. In the process of coordination and communication, the wide use of information technology has also been the basis for the smooth implementation of such work. The plan clearly stipulated that more than 20 museums and art venues would be built as public spaces in brownfields and construction areas with a total area of 9.4 square kilometers by the end of 2020, taking the renovation of brownfields in Xuhui District of Shanghai as an example (Shanghai Observer, 2016). In interviews, many officials and staffs told us that there were dozens of coordination work meetings attended by the district governor. In addition, the number of other formal and informal communications has become uncountable.

After the completion of the planning, the enterprises that had agreed with the planning goal began to participate in the specific transformation, and the government, as the main body of public management, withdrew from the transformation process at that time. The work that needed to be further coordinated has been carried out by a government agency, the development company of the corresponding land. At that time, the industrial heritage transformation had entered the market-oriented operation stage. All enterprises involved in the transformation have followed the law of market operation. The government had no longer interfered with the specific 
work in the transformation process, but continued to act as the administrator and the provider of public services to guarantee the implementation of the plan with legal benefits and the interests of the public and all parties involved. All enterprises involved in the transformation first agreed with the clear objectives and methods of the government led planning. After entering the transformation process of industrial heritage, they formed interdependent and relatively stable relationships, and they have had a lot of interaction, coordination and communication. Massive communication and coordination have existed in the structure, to allow information to spread rapidly through various formal or informal ways.

Information technology, including a variety of social media based on mobile internet, has provided an efficient communication channel for complex communication and coordination. For example, during the development of Shanghai Binjiang industrial heritage, all the staff involved in this network structure communicated on WeChat, China's largest social platform. This social app was installed on everyone's mobile phone to ensure that all kinds of information received timely feedback. At the same time, WeChat supported the transmission of text, pictures, voice, video and other file formats. Many times, various texts were edited directly in the mini application supported by WeChat platform, and then shared in the group. All parties who had modification suggestions could timely participate in and understand the latest changes of each text, greatly improving the work efficiency.

In this network structure supported by information technology, development companies - including government agents and all other participants - have functioned with no formal authority relationship among them. Each participant has been treated as an independent legal entity. In the process of jointly completing the industrial heritage transformation, they have cooperated with each other and have been able to exercise their own authority at the same time. Due to the fact that these organizations often needed to coordinate many relationships to ensure the implementation of planning objectives in all aspects, there has been flexibility regarding the structure of power relationship. The governments development company has not been given more power than other entities involved in the process, but it has been in the center of the whole network. Compared with other companies in the network, the government unit has had more direct contact with all the other parties involved, especially through WeChat. In interviews with the staff of the government company, we've learned that they created and participated in hundreds of various work groups. Some of these groups were dissolved automatically after the completion of a stage of the work, others have been in existence throughout the whole process of transformation. This kind of informal structure has ensured efficient communication and coordination, enabling participating organizations to constantly change their tasks according to the needs of network operation, always drive the network operation, and ensure the final implementation of planning objectives.

This network power structure has effectively guaranteed the efficient and smooth renovation of a number of industrial heritage projects. West Bund Museum opened in 
March 2014, which was converted from an abandoned coal terminal. It was designed and built by Chinese architect Liu Yichun, who is one of the partners of Deshaus Architecture \& Design. The total construction area is about 33,000 square meters. The display area reaches 16,000 square meters (Long Museum, 2020). Yuz Museum Shanghai was launched in the same year, through the transformation of a large hangar located at the abandoned Longhua Airport. The total construction area is more than 9,000 square meters, designed by Japanese architect Sou Fujimoto (Yuz Museum, 2020). Tank Shanghai, a non-profit art institution that was launched in 2019, consists of the transformation of five abandoned jet fuel tanks with pure thick steel plate structure, with a total construction area of 11,029 square meters (Tank Shanghai, 2020). The Shanghai Dream Center currently under construction is one of the largest commercial and cultural projects in China, with a total investment of 460,000 square meters. Among them, the Dream Dome, with its 2,500 seats, has been built on the structure of the original Shanghai Cement Plant (Shanghai Dream Centre, 2020).

This network power structure has been located between the market and the government's governance institutions. This strategy has effectively ensured that the government-led planning can be implemented, and has also retained the characteristics of market efficiency. The establishment of such a power structure between the bureaucratic government and the market has been the practical embodiment of the government's holistic governance philosophy in the process of the transformation of industrial heritage.

After the initial transformation of industrial heritage, the central network structure with the development company as the main agent also changes. The companies that implement the development and construction functions gradually withdraw from the network structure. They are replaced by companies and institutions that operate public venues, such as art galleries and concert halls. The Long Museum mentioned above is a private art museum founded by Chinese collectors Liu Yiqian and Wang Wei. Yu Deyao Art Museum is supported by the famous Indonesian-Chinese collector Mr. Yu Deyao and by his foundation. In addition, representatives of residential communities, park office management organizations and public green space maintenance units are all involved in this network structure as integral operation participants. In this process, the development company, as the government agency, is still in the center of the network structure and maintains direct interaction and contact with these other entities, which carry out market-oriented operation according to the contract and contractual relationship. At the same time, this network structure is an open structure. Through the mechanism of market competition, enterprises that are more efficient and provide better services can enter the competition at any time and eliminate companies that were originally in the network structure.

In the whole process of network operation, in order to prevent or put an end to potential company corruption and power rent-seeking, development companies are usually state-owned enterprises. The evaluation standard for them is no longer the priority of economic interests, but the priority of social benefits over economic ben- 
efits. The leaders of development companies are also supervised through the evaluation method of civil servants.

Therefore, in the transformation and operation of industrial heritage, the idea of holistic governance is first expressed in the form of a government-led planning scheme, and materialized through the construction of a network structure involving government and market, by using the technical support of the information industry to effectively promote the smooth implementation of planning objectives and plans.

\section{Conclusion}

With the progress of science and technology and the upgrading of industry, the transformation of industrial heritage is a global topic. How to effectively transform and, at the same time, protect the public rights and interests, is the focus of governments and academics. Through our analysis of an important industrial heritage transformation case, and through dialog with representatives of the government, of enterprises and of surrounding residents, we have found that - under the guidance of holistic governance - using a flexible network power structure to couple the public administration and market is a valuable transformation idea. This idea enables the government to maintain the overall cooperation of planning, transformation and operation on the basis of maintaining the high efficiency of market competition. The strategy makes use of various forces, including mass media, strengthens the integrity of the transformation and operation, and maximizes the efficiency of industrial heritage transformation and its social value. Not only in China, but worldwide, the transformation of industrial heritage can be done only with the deep involvement of the government. The transformation of industrial heritage carried out by the city Shanghai under the guidance of holistic governance ideology has been effective in terms of competition efficiency and overall coordination. It has also answered questions regarding the transition from enterprise leadership to public management and the use of optimal management strategies and policies in the transformation of industrial heritage.

\section{References:}

1. Altena, B. and van der Linden, M., De-industrialization: Social, Cultural and Political Aspects, Cambridge: Cambridge University Press, 2002.

2. Baidu Baike, Official Website, 2020, [Online] available at https://baike.baidu.com/item/\%E 9\%93\%81\%E6\%A1\%A5\%E5\%B3\%A1\%E8\%B0\%B7, accessed on May 25, 2020.

3. China Soil Pollution Status Survey Bulletin, 2014, [Online] available at http://society. people.com.cn/n/2014/0417/c1008-24910096-2.html, accessed on February 14, 2020.

4. Del Pozo, P.B. and Gonzales, P.A., 'Industrial Heritage and Place Identity in Spain: From Monuments to Landscapes', 2012, Geographical Review, vol. 102, no. 4, pp. 446-464.

5. Hood, C., 'A Public Management for All Seasons', 1991, Public Administration, vol. 69, no. 1, pp. 3-19.

6. Long Museum West Bound, Official Website, 2020, [Online] available at http://www. thelongmuseum.org/en/page-3-1005.html, accessed on June 12, 2020. 
7. Orange, H., 'Industrial Archaeology: Its Place within the Academic Discipline, the Public Realm and the Heritage Industry', 2008, Industrial Archaeology Review, vol. 30, no. 2, pp. 83-95.

8. Pollit, C., 'Joined-up Government: A Survey', 2003, Political Studies Review, vol. 1, no. 1, pp. 34-39.

9. Shanghai Dream Centre, 'Culture Information', 2020, [Online] available at http://shang haidreamcenter.com/en/culture.html, accessed on May 25, 2020.

10. Shanghai Government, Shanghai Government Official Website, 2018, [Online] available at http://www.shanghai.gov.cn/nw2/nw2314/nw2319/nw12344/u26aw56058.html, accessed on May 25, 2020.

11. Shanghai Observer, Shanghai Observers Official Website, 2016, [Online] available at https://www.shobserver.com/news/detail?id=28393, accessed on July 15, 2020.

12. Tank Shanghai, Official Website, 2020, [Online] available at http://tankshanghai.com/en/ about/info22.htm, accessed on June 15, 2020.

13. General Office of Shanghai Municipal Government, 'The Comprehensive Work Plan for Energy Conservation, Emission Reduction and Greenhouse Gas Emission Control of Shanghai During the 13th Five-Year Plan Period' (in Chinese), May 18, 2018. [Online] available at http://www.shanghai.gov.cn/nw42236/20200823/0001-42236_1314804.html, accessed on June 15, 2020.

14. UNESCO, UNESCO World Heritage Centre World Heritage List, 2020, [Online] available at http://whc.unesco.org/en/list/, accessed on June 10, 2020.

15. Yuz Museum Shanghai, About Us, 2020, [Online] available at http://www.yuzmshanghai. org/about-yuz-museum-shanghai/?lang=en /, accessed on June 10, 2020.

16. Zhang, C.L. and Liu, Y.G., 'The Transformation of Zeche Zollverein in the Ruhr Area: Experience of Multi-Agent Governance' (in Chinese), 2020, fournal of Natural Resources, vol. 35 , no. 4 , pp. 884-894. 